\title{
Accuracy and precision study of gas flow matching in LA-ICP-MS for zircon $\mathrm{U}-\mathrm{Pb}$ dating analysis
}

\author{
XiJUAn TAN ${ }^{1}$,Ting LianG ${ }^{2}$, YongGang FenG ${ }^{3}$ \\ ${ }^{1}$ Laboratory of Mineralization and Dynamics, Chang'an \\ University, Xi'an, China, 710054, \\ tanxijuan@hotmail.com \\ ${ }^{2}$ Laboratory of Mineralization and Dynamics, Chang'an \\ University, Xi'an, China, 710054, liangt@chd.edu.cn \\ ${ }^{3}$ Laboratory of Mineralization and Dynamics, Chang'an \\ University, Xi'an, China, 710054, ygfeng@chd.edu.cn
}

Zircon U-Pb dating is an efficient strategy to determine the age and origin of rocks. Following TIMS and SHRIMP, LA-ICP-MS has been accepted as a geochronological tool to determine U-Pb zircon ages over the past decades [1]. Although LA-ICP-MS exhibits conspicuous advantages inclduing short analytical time, moderate spatial resolution, and relatively low cost [2], stringent precision and accuracy control is still the prerequisite for its applcation in zircon geochronologic studies. In this work, we investigated the influence of gas flow setting of abltion cell gas and carrier gas on U-Pb dating accuracy and precision by LA-ICP-MS. After being produced by Photon-machines $193 \mathrm{~nm}$ excimer laser, zircon 91500 aerosols were transported by ablation cell gas helium $(\mathrm{He})$ first and mixed with a subsequent carrier gas argon (Ar) to Agilent 7700x ICP-MS. With fixed Ar of 1.0 $\mathrm{L} / \mathrm{min}$, it was found that the obtained average ${ }^{206} \mathrm{~Pb} /{ }^{238} \mathrm{U}$ ages of zircon 91500 incresed from 1001.97 to 1070.77 with $\mathrm{He}$ from 0.2 to $0.8 \mathrm{~L} / \mathrm{min}$, showing decreasing $1 \sigma$ from 35 to 20 and increasing cordance from $92 \%$ to $98 \%$. Additionally, the results of $0.8 / 0.8$ and $0.6 / 0.6 \mathrm{~L} / \mathrm{min}$ of $\mathrm{He} / \mathrm{Ar}$ gas flow settings showed the respective average ${ }^{206} \mathrm{~Pb} /{ }^{238} \mathrm{U}$ ages of $1076.65(1 \sigma=19$, cordance: $97 \%)$ and $1064.99(1 \sigma=30$, cordance: $89 \%$ ). Clearly, lower He and Ar gas flow matching has big age bias, demonstrating the great effect of gas flow matching on accuracy and good precision of zircon ages. However, the detailed maching machnism of ablation cell gas flow and carrier gas in zircon U-Pb dating analysis needs further investigation.

Keywords: gas flow matching, zircon U-Pb dating, LA-ICPMS

\section{References}

[1] R Mundil, KR Ludwig, I Metcalfe, et al., Science, 2004, 305: 1760-1763.

[2] Z Chang, JD Vervoort, WC Mcclelland, et al., Geochemistry Geophysics Geosystems, 2006, 7: Q05009. 